\title{
Smoke Production from Cell Wall Materials of Tobacco Leaves*
}

\author{
by \\ Yosbiaki Isbizu, Kazuyo Kaneki \\ and Kazno Izawa \\ Tobacco Science Research Laboratory, \\ Japan Tobacco Inc., \\ Yokohama, Japan
}

\section{SUMMARY}

Major components of cell wall materials, that is $\alpha$-cellulose, hemicellulose, pectin and lignin, were isolated from tobacco leaves. They were heated in a micro-thermobalance in different atmospheres and at different heating rates. The weight loss rate of the sample materials, production rates of carbon oxides and smoke particles produced were measured. In general, materials which produce more carbon oxides produce less smoke particulate mass. In helium at a heating rate of $240^{\circ} \mathrm{C} / \mathrm{min}$, which attempts to approximate the burning conditions of a cigarette, weight ratios of smoke particles to the sample weight were $32 \%$ for $\alpha$-cellulose, $24 \%$ for lignin, $3 \%$ for hemicellulose and $0.4 \%$ for pectin. Since $\alpha$-cellulose is a major constituent of the cell wall of tobacco leaves and has the highest production rate, it can be concluded that $\alpha$-cellulose is a major contributor to the production of smoke particles from cigarettes. On the contrary, pectin contributes the least.

\section{ZUSAMMENFASSUNG}

Die Hauptbestandteile der Zellwand, und zwar $\alpha$-Zellulose, Hemizellulose, Pektin und Lignin, wurden aus Tabakblättern isoliert. Sie wurden in einer Mikro-Thermowaage in verschiedenen Medien unterschiedlich schnell erhitzt. Dabei wurde die Gewichtsabnahme der Probe sowie die Bildung von Oxiden des Kohlenstoffs

Received: 1st September 1989 - accepted 15th January 1990 und Rauchpartikeln gemessen. Grundsätzlich ist festzustellen, daß sich bei Stoffen, bei deren Erhitzen mehr Kohlenstoffoxide entstehen, weniger Rauchpartikel bilden. Werden die Stoffe in Helium mit $240^{\circ} \mathrm{C} / \mathrm{min}$ aufgeheizt - der Versuch, näherungsweise die Bedingungen beim Abrauchen einer Zigarette zu simulieren -, beträgt das Gewichtsverhältnis zwischen Rauchpartikeln und Probe $32 \%$ für $\alpha$-Zellulose, 24\% für Lignin, 3\% für Hemizellulose und $0,4 \%$ für Pektin. Da $\alpha$-Zellulose ein Hauptbestandteil der Zellwand in Tabakblättern ist und auch im Versuch vorrangig entsteht, kann die Schlußfolgerung gezogen werden, daß die Entstehung von Rauchpartikeln beim Zigarettenrauchen hauptsächlich auf $\alpha$-Zellulose zurückzuführen ist. Pektin trägt dagegen am wenigsten dazu bei.

\section{RESUME}

Les composants principaux de la membrane cellulaire du tabac, telles que la $\alpha$-cellulose, l'hémicellulose, la pectine et la lignine, ont été isolées à partir de feuilles de tabac et chauffées dans une balance microthermique dans des milieus différents et à des vitesses variables. On a mesuré simultanément la perte de poids de l'échantillon ainsi que le taux de production d'oxydes de carbones et de particules de fumée. Il est généralement apparu que plus le composant produit d'oxydes de carbones moins il produit de particules de fumée. Lorsque l'échantillon est chauffée sous hélium à $240^{\circ} \mathrm{C} / \mathrm{min}$, conditions proches de la combustion d'une cigarette, le rapport poids des particules de fumée sur poids de l'échantillon est de $32 \%$ pour la $\alpha$-cellulose, de $24 \%$ pour la lignine, de $3 \%$ pour l'hémicellulose et de $0,4 \%$ pour la pectine. Etant donné que l' $\alpha$ - 
cellulose est un composant essentiel de la membrane cellulaire de la feuille de tabac et que son taux de croissance est le plus élevé, nous pouvons conclure que l' $\alpha$ cellulose est le facteur déterminant de la production de particules de fumée de cigarettes.

\section{INTRODUCTION}

Although the study of smoke formation is essential to understanding how cigarettes work, only a few studies have been published because it is a complicated chemical and physical process (1). Among these studies, gaseous components such as carbon oxides have been mainly studied (2-5).

In a previous paper (6), physical properties of smoke particles produced from thermal analysis of tobacco leaves were examined and their dependence upon the atmosphere and heating rates was reported.

To investigate the smoke formation mechanism further, major components of cell wall materials of tobacco leaves were isolated and heated in different atmospheres and at different heating rates. In addition to the size and concentration of smoke particles, the concentrations of carbon oxides produced from each material were measured and discussed.

\section{EXPERIMENTAL METHOD}

Materials used for the experiments were $\alpha$-cellulose, hemicellulose, pectin and lignin, which had been isolated from Burley tobacco leaves following the commonly used method (7) as shown in Figure 1. These materials were ground to pass through 80 -mesh sieves. The experimental apparatus is schematically shown in Figure 2. Thermal analysis was carried out by a rapid heating micro-thermobalance equipped with an infrared image furnace (Shinku Riko Co. Ltd., Model TG-3000) under an atmosphere of air or helium. In each atmosphere, the heating rate was set at either of two levels: $10^{\circ} \mathrm{C} / \mathrm{min}$ and $240^{\circ} \mathrm{C} /$ $\min$. The heating rate, $240^{\circ} \mathrm{C} / \mathrm{min}$, was chosen to correspond to the actual static burn of a cigarette (8) and the flow rate of the gas was $0.11 / \mathrm{min}$. Carbon oxides and smoke particles generated in the furnace were diluted by helium or clean air at $10 \mathrm{l} / \mathrm{min}$. The diluted smoke was then fed simultaneously to a $\mathrm{CO}$ meter (GASTECH Co. Ltd, Model CM-2510) and a $\mathrm{CO}_{2}$ meter (Fuji Electric Co. Ltd. Model ZFP). In addition, it was also fed simultaneously to a piezobalance mass monitor (Nihon Kagaku Kogyo Co. Ltd., Model 51-1111) and a laser particle counter (Hitachi Electronics Engineering Co. Ltd., Model TSI 600) so that the mass concentration and the size distribution of smoke particles could also be measured.
Figure 1.

Method for isolating cell wall materials from tobacco leaves.

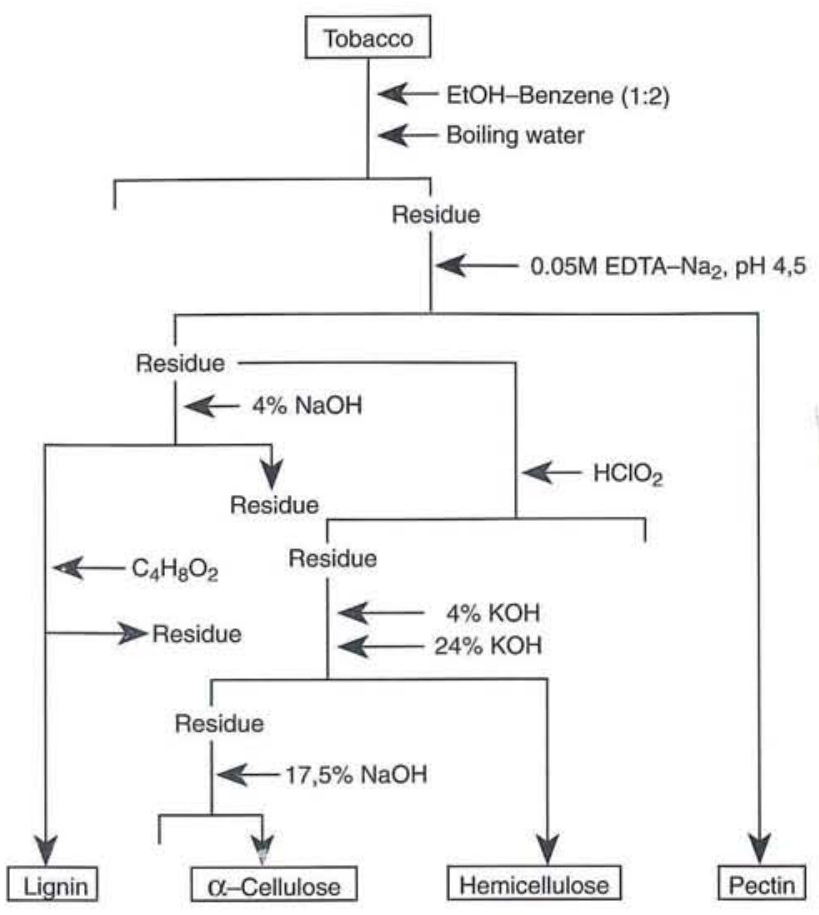

Figure 2.

Schematic diagram of experimental apparatus.

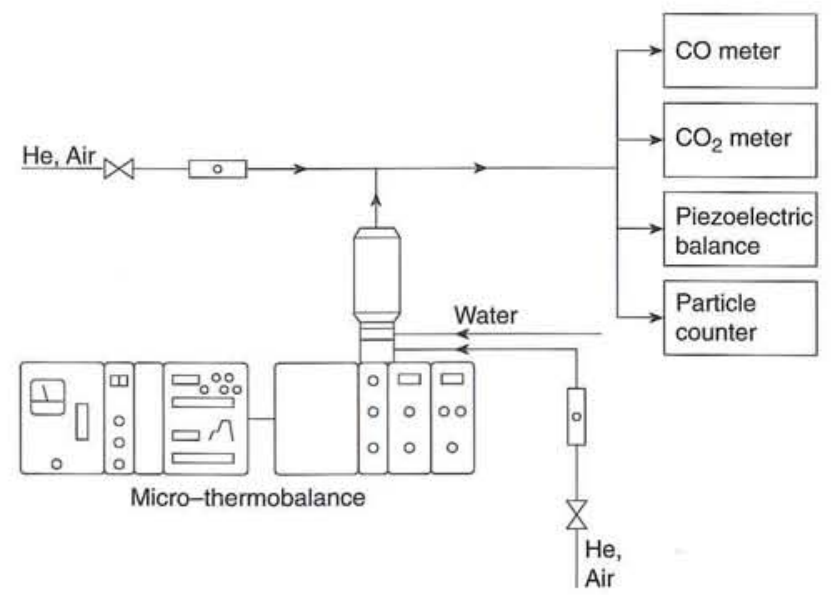

\section{RESULTS}

$\alpha$-Cellulose

The results when $\alpha$-cellulose was heated in air at a heating rate of $10^{\circ} \mathrm{C} / \mathrm{min}$ are shown in Figure 3a. Two peaks were observed for the weight loss rate. The first peak at about $300{ }^{\circ} \mathrm{C}$ is well known and is due to the pyrolysis of $\alpha$-cellulose. Corresponding to this peak, carbon oxides and smoke particles were produced. The second peak at 


\section{Figure 3a.}

Weight loss rate, and production rates of carbon oxides and smoke particles from $1.39 \mathrm{mg}$ of $\alpha$-cellulose in air at the heating rate of $10^{\circ} \mathrm{C} / \mathrm{min}$.
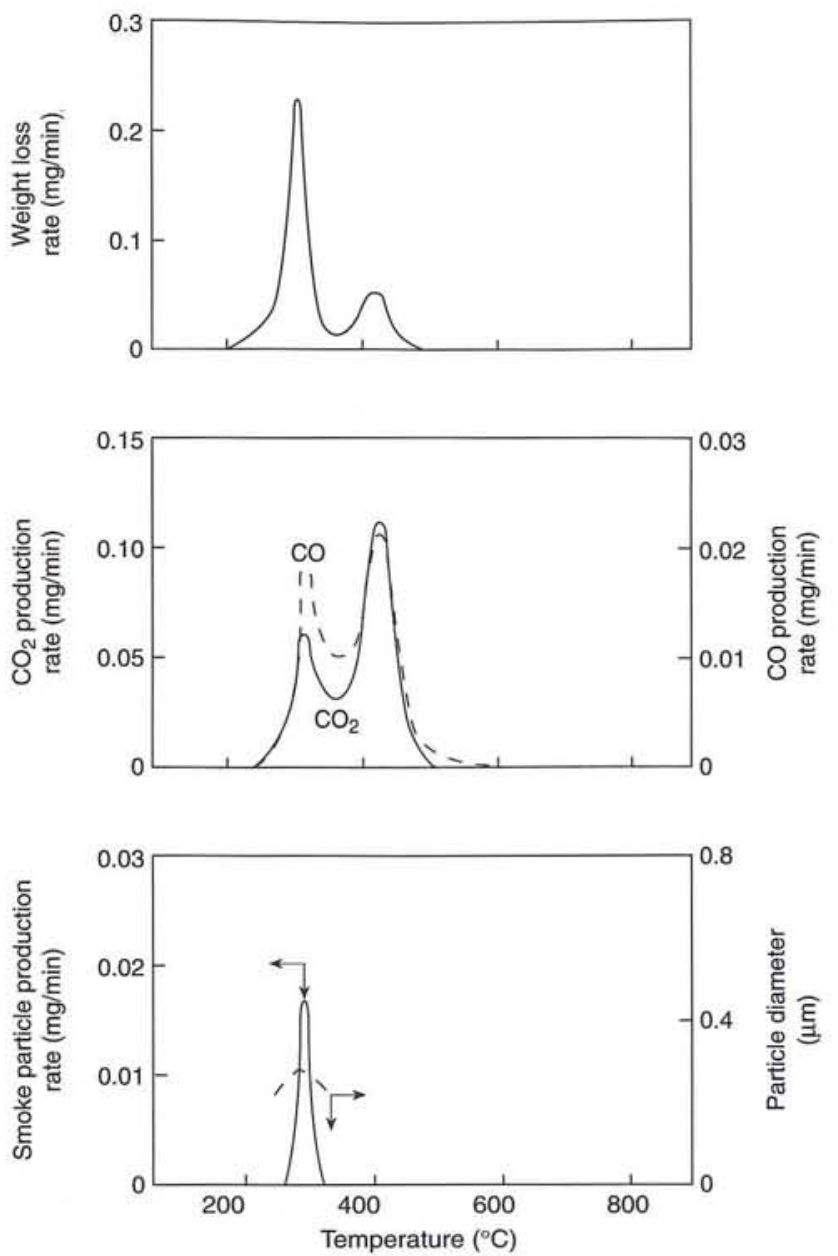

about $400^{\circ} \mathrm{C}$ is due to the combustion of residual char. No smoke particles were detected at the temperature corresponding to this peak since the products of the combustion are gaseous compounds such as carbon monoxide, carbon dioxide and water.

In the atmosphere of helium, only the weight loss rate maximum related to pyrolysis can be seen in Figure $3 \mathrm{~b}$. Production of carbon oxides was much less than that in air, but more smoke particulate mass was produced. The geometric mean diameter was about $0.3 \mu \mathrm{m}$ and this was a little larger than that in air.

Figure $3 \mathrm{c}$ shows the results obtained in air at a heating rate of $240^{\circ} \mathrm{C} / \mathrm{min}$. Since the heating rate was very fast, the weight loss rate and production rate of smoke, both carbon oxides and particles, were about ten times faster than those at $10^{\circ} \mathrm{C} / \mathrm{min}$. The average particle size is not depicted in this Figure because most of the smoke particles were beyond the measurement range of the instrument, that is above $0.8 \mu \mathrm{m}$.
Figure $3 \mathrm{~b}$.

Weight loss rate, and production rates of carbon oxides and smoke particles from $1.27 \mathrm{mg}$ of $\alpha$-cellulose in helium at the heating rate of $10^{\circ} \mathrm{C} / \mathrm{min}$.
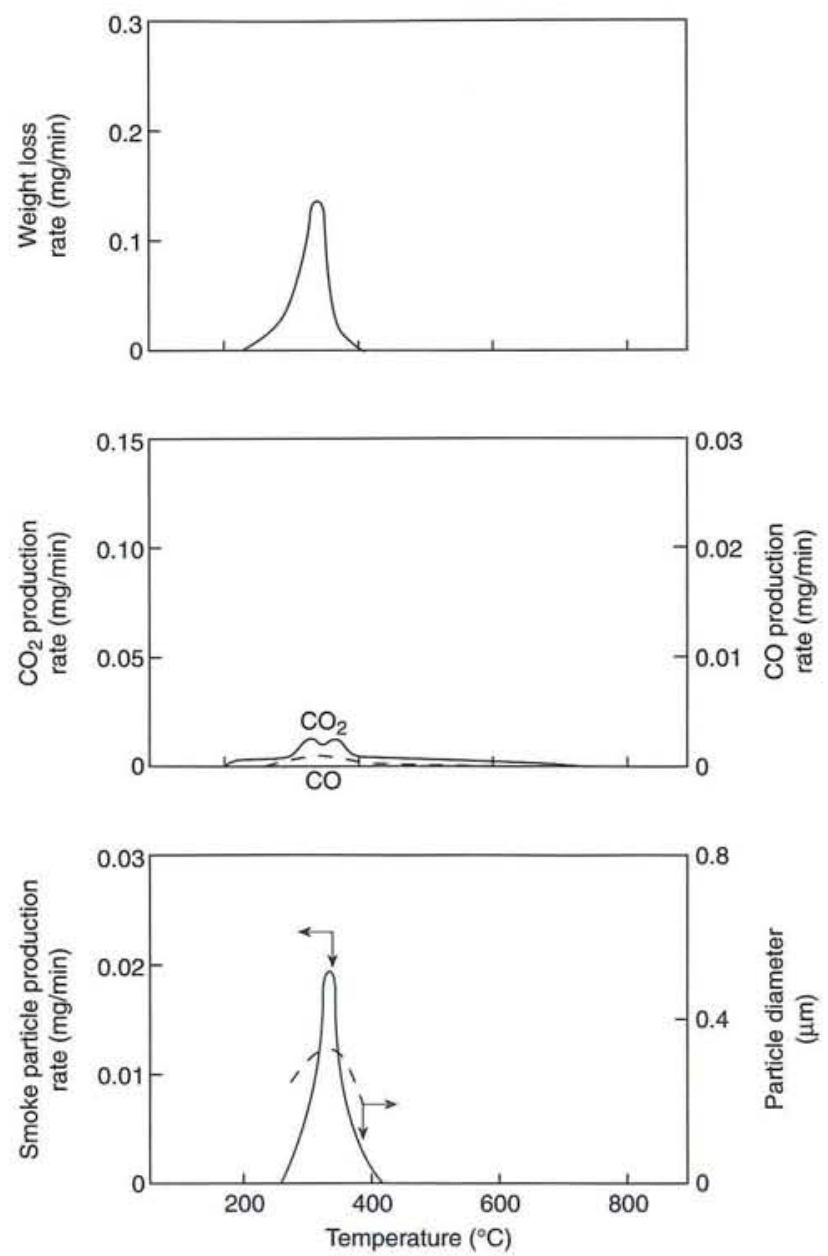

Figure $3 \mathrm{~d}$ shows the results obtained in helium at the same heating rate of $240{ }^{\circ} \mathrm{C} / \mathrm{min}$. As is the case for an atmosphere of air, the weight loss rate and smoke production rate were about ten times larger than those at $10^{\circ} \mathrm{C} / \mathrm{min}$. The average particle size was larger than $0.8 \mu \mathrm{m}$.

\section{Hemicellulose}

When the heating rate was $10^{\circ} \mathrm{C} / \mathrm{min}$, the weight loss rate showed a maximum with several shoulders at about $250^{\circ} \mathrm{C}$ both in air and helium as shown in Figures $4 \mathrm{a}$ and $4 \mathrm{~b}$. No smoke particles were detected, at least up to $5 \mathrm{mg}$ of sample material, but more carbon oxides were produced compared to $\alpha$-cellulose. At temperatures of more than $600^{\circ} \mathrm{C}$, the production of carbon dioxide was dominant in air, while carbon monoxide was predominantly formed in helium. 
Figure 3c.

Weight loss rate, and production rates of carbon oxides and smoke particles from $0.86 \mathrm{mg}$ of $\alpha$-cellulose in air at the heating rate of $240^{\circ} \mathrm{C} / \mathrm{min}$.
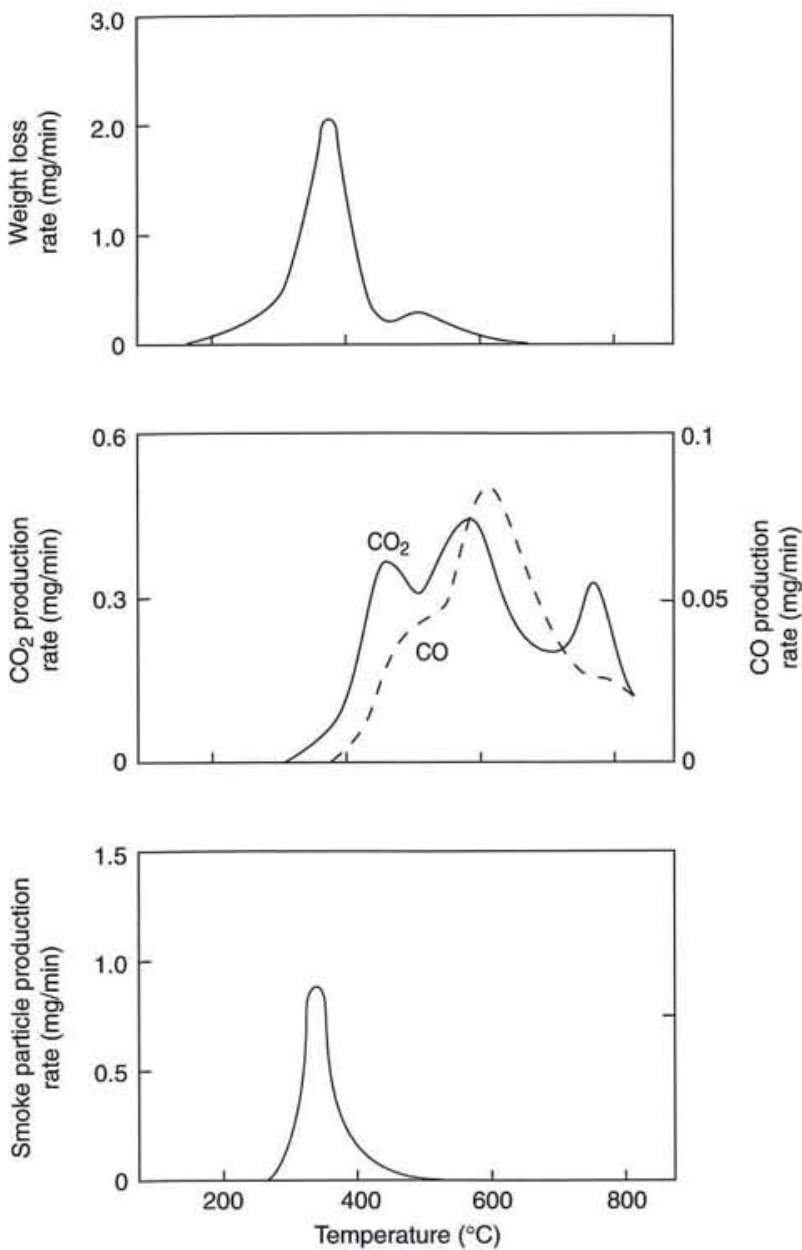

When the heating rate was $240^{\circ} \mathrm{C} / \mathrm{min}$, virtually, only one peak in the weight loss rate was found at about $300{ }^{\circ} \mathrm{C}$ as shown in Figures $4 \mathrm{c}$ and $4 \mathrm{~d}$. The production rate of carbon oxides was more than ten times larger compared to the rate found at $10^{\circ} \mathrm{C} / \mathrm{min}$ and only a small amount of smoke particles was detected. Further, as in the case of the slower heating rate, the production of carbon dioxide was dominant in air at higher temperatures, but a large amount of carbon monoxide was produced in a helium atmosphere. The change in average particle size was similar to that of smoke particle production rate.

\section{Pectin}

The results for pectin are shown in Figures $5 \mathrm{a}, \mathrm{b}, \mathrm{c}, \mathrm{d}$. As for hemicellulose, no particles were detected at a heating rate of $10^{\circ} \mathrm{C} / \mathrm{min}$. The weight loss rate was fastest at about $250^{\circ} \mathrm{C}$, where carbon oxides were produced. At
Figure 3d.

Weight loss rate, and production rates of carbon oxides and smoke particles from $0.71 \mathrm{mg}$ of $\alpha$-cellulose in helium at the heating rate of $240{ }^{\circ} \mathrm{C} / \mathrm{min}$.
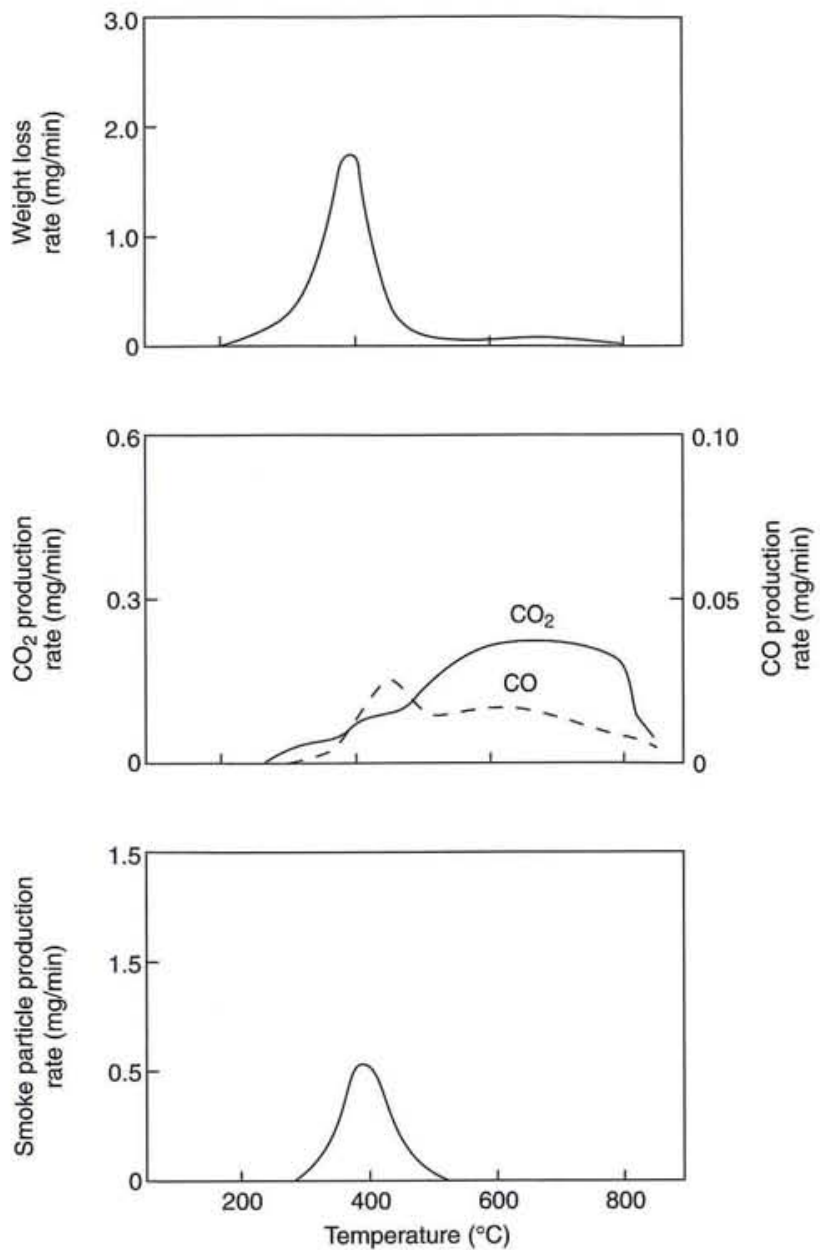

higher temperatures of about $700^{\circ} \mathrm{C}$, production of carbon dioxide was dominant in air, while a significant amount of carbon monoxide was produced in helium, as in case of hemicellulose. When the heating rate was $240^{\circ} \mathrm{C} / \mathrm{min}$, the production of carbon oxides showed two maxima at about $300^{\circ} \mathrm{C}$ and $750^{\circ} \mathrm{C}$.

As for smoke particles, a small amount was detected both in air and in helium but their geometric mean diameter was considerably larger. The change in the average size was similar to the change in smoke particle production rate.

\section{Lignin}

When lignin was heated at a rate of $10^{\circ} \mathrm{C} / \mathrm{min}$ in air, three peaks appeared in the weight loss rate profile as shown in Figure 6a. Production of carbon oxides was the highest at temperatures of about $500^{\circ} \mathrm{C}$ corresponding to the third 
Figure $4 \mathrm{a}$.

Weight loss rate, and production rates of carbon oxides and smoke particles from $2.16 \mathrm{mg}$ of hemicellulose in air at the heating rate of $10^{\circ} \mathrm{C} / \mathrm{min}$. No smoke particles were observed.
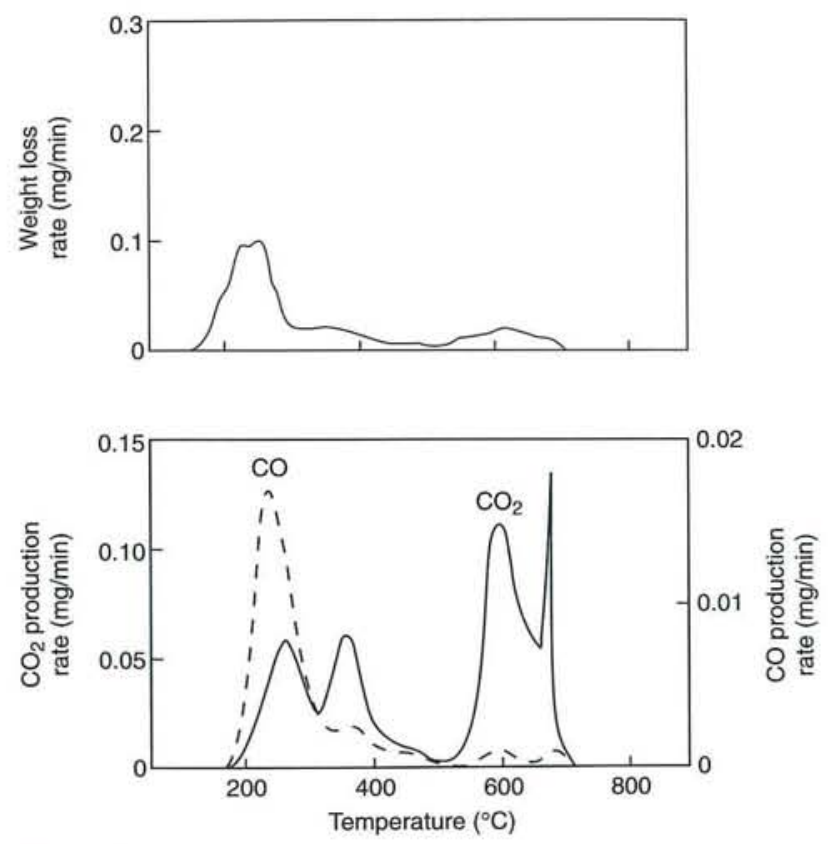

Figure $4 \mathrm{c}$.

Weight loss rate, and production rates of carbon oxides and smoke particles from $4.17 \mathrm{mg}$ of hemicellulose in air at the heating rate of $240{ }^{\circ} \mathrm{C} / \mathrm{min}$.
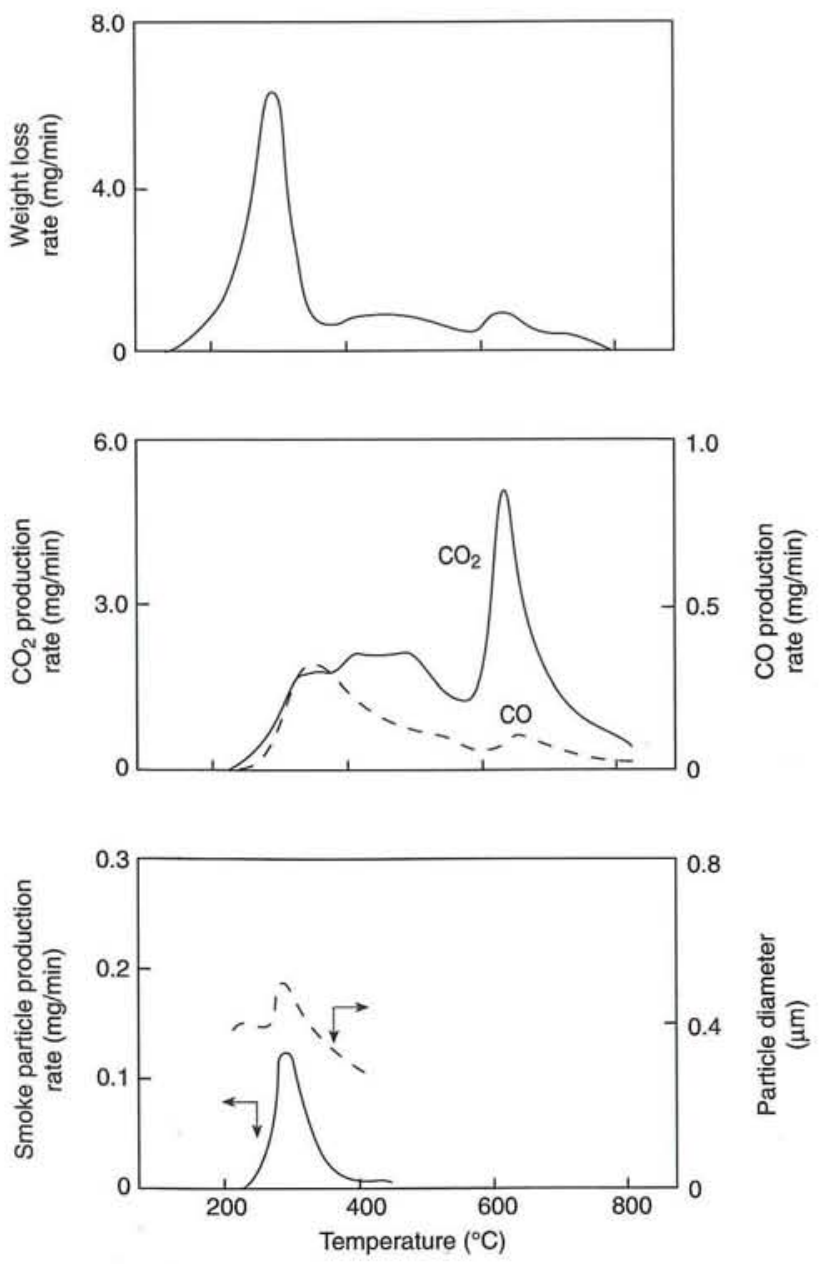

Figure 4b.

Weight loss rate, and production rates of carbon oxides and smoke particles from $2.22 \mathrm{mg}$ of hemicellulose in helium at the heating rate of $10^{\circ} \mathrm{C} / \mathrm{min}$. No smoke particles were observed.
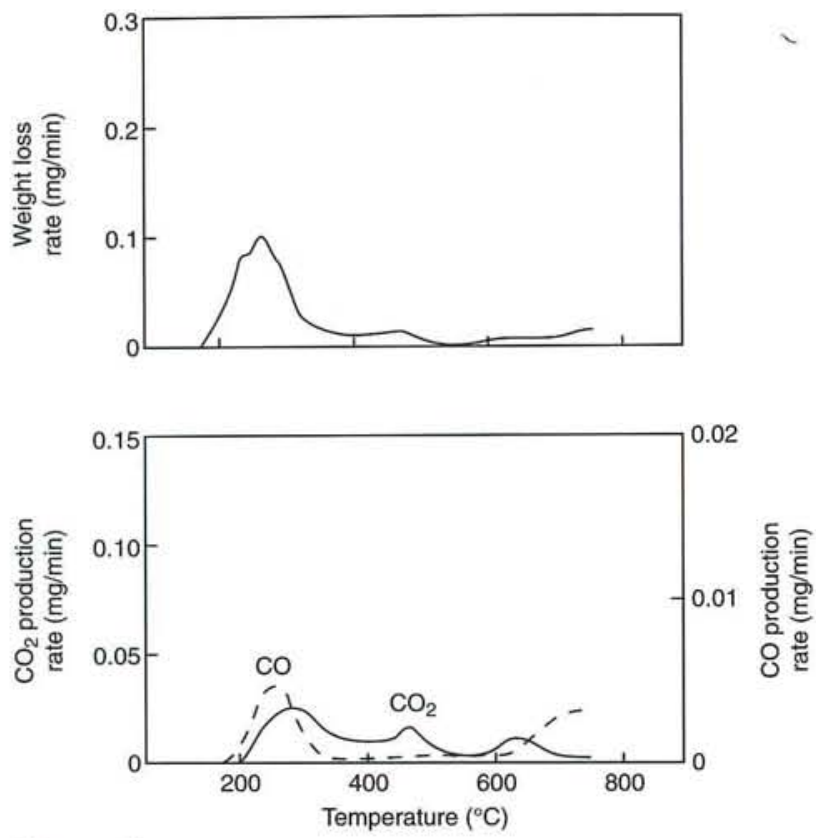

Figure 4d.

Weight loss rate, and production rates of carbon oxides and smoke particles from $4.19 \mathrm{mg}$ of hemicellulose in helium at the heating rate of $240{ }^{\circ} \mathrm{C} / \mathrm{min}$.
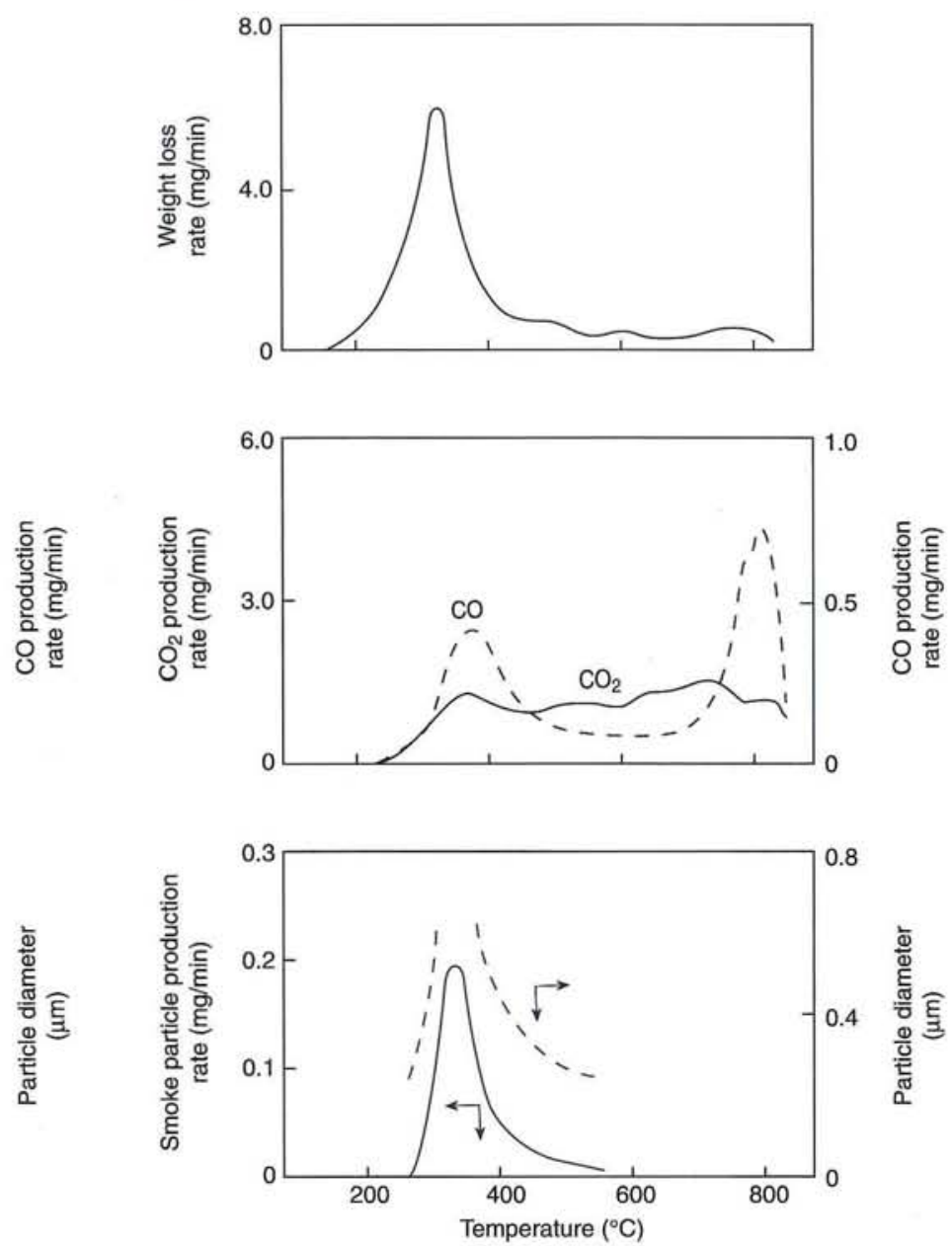
Figure 5 a.

Weight loss rate, and production rates of carbon oxides and smoke particles from $2.01 \mathrm{mg}$ of pectin in air at the heating rate of $10^{\circ} \mathrm{C} / \mathrm{min}$. No smoke particles were observed.
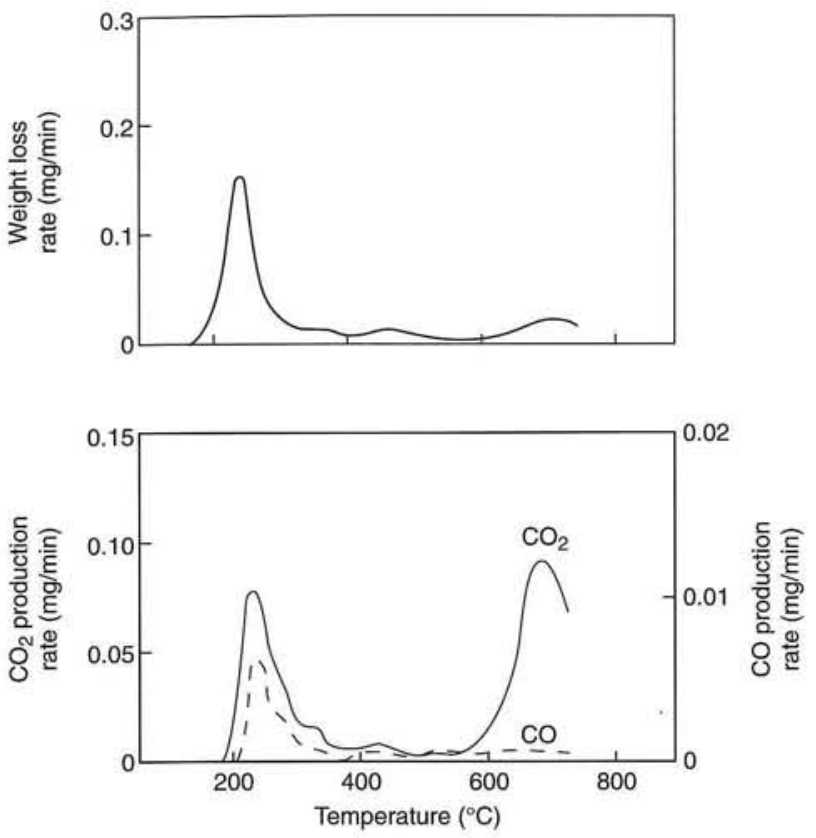

Figure $5 \mathrm{c}$.

Weight loss rate, and production rates of carbon oxides and smoke particles from $3.10 \mathrm{mg}$ of pectin in air at the heating rate of $2400^{\circ} \mathrm{C} / \mathrm{min}$.
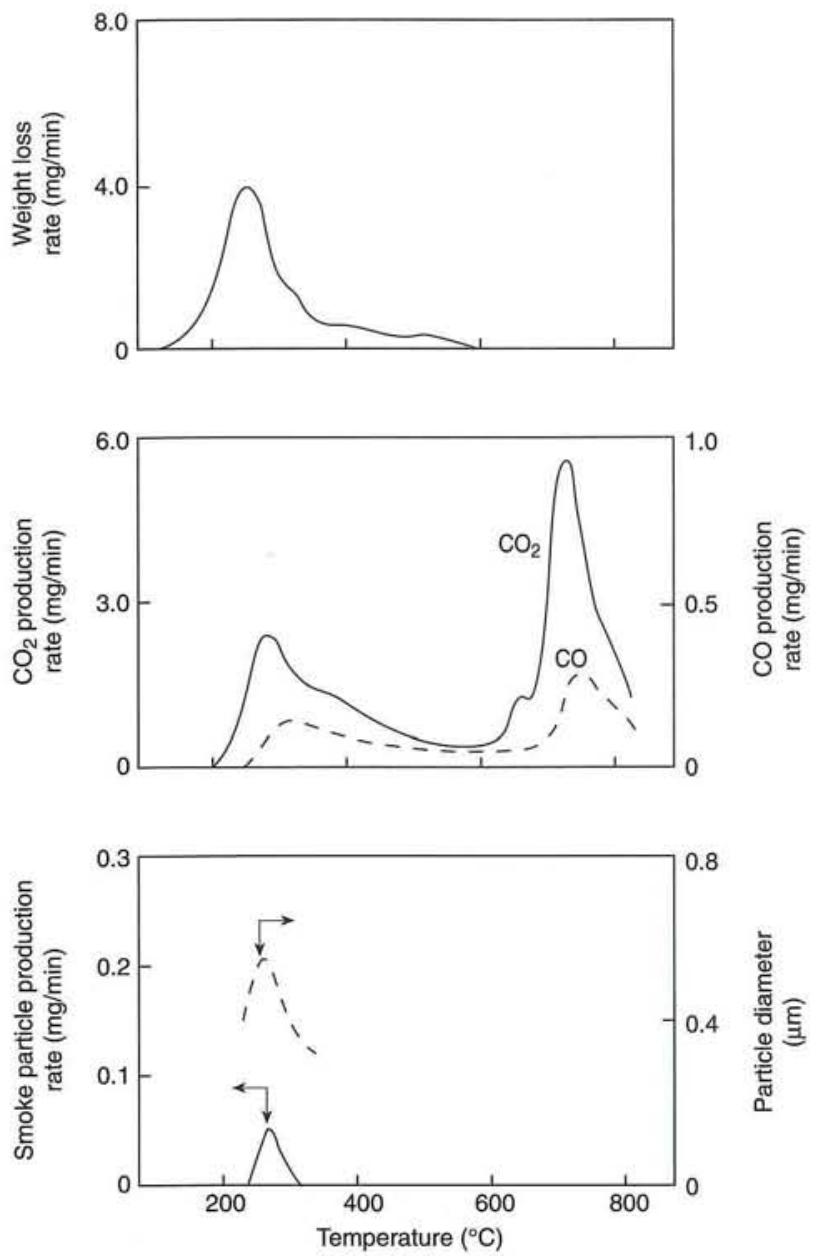

Figure $5 b$.

Weight loss rate, and production rates of carbon oxides and smoke particles from $2.09 \mathrm{mg}$ of pectin in helium at the heating rate of $10{ }^{\circ} \mathrm{C} / \mathrm{min}$. No smoke particles were observed.
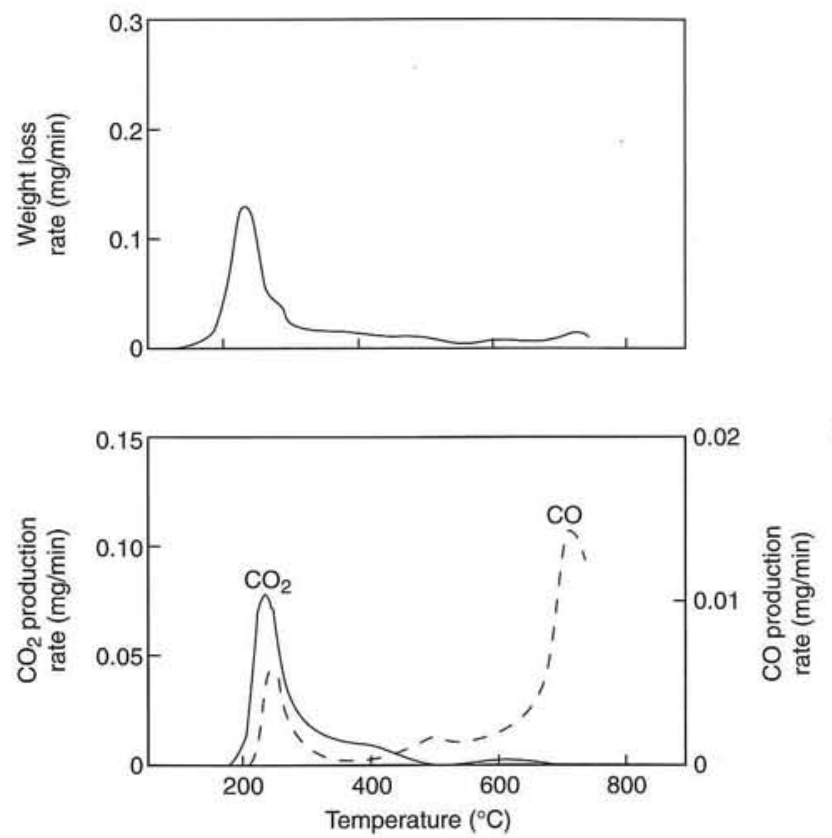

Figure $5 \mathrm{~d}$.

Weight loss rate, and production rates of carbon oxides and smoke particles from $3.98 \mathrm{mg}$ of pectin in helium at the heating rate of $240^{\circ} \mathrm{C} / \mathrm{min}$.
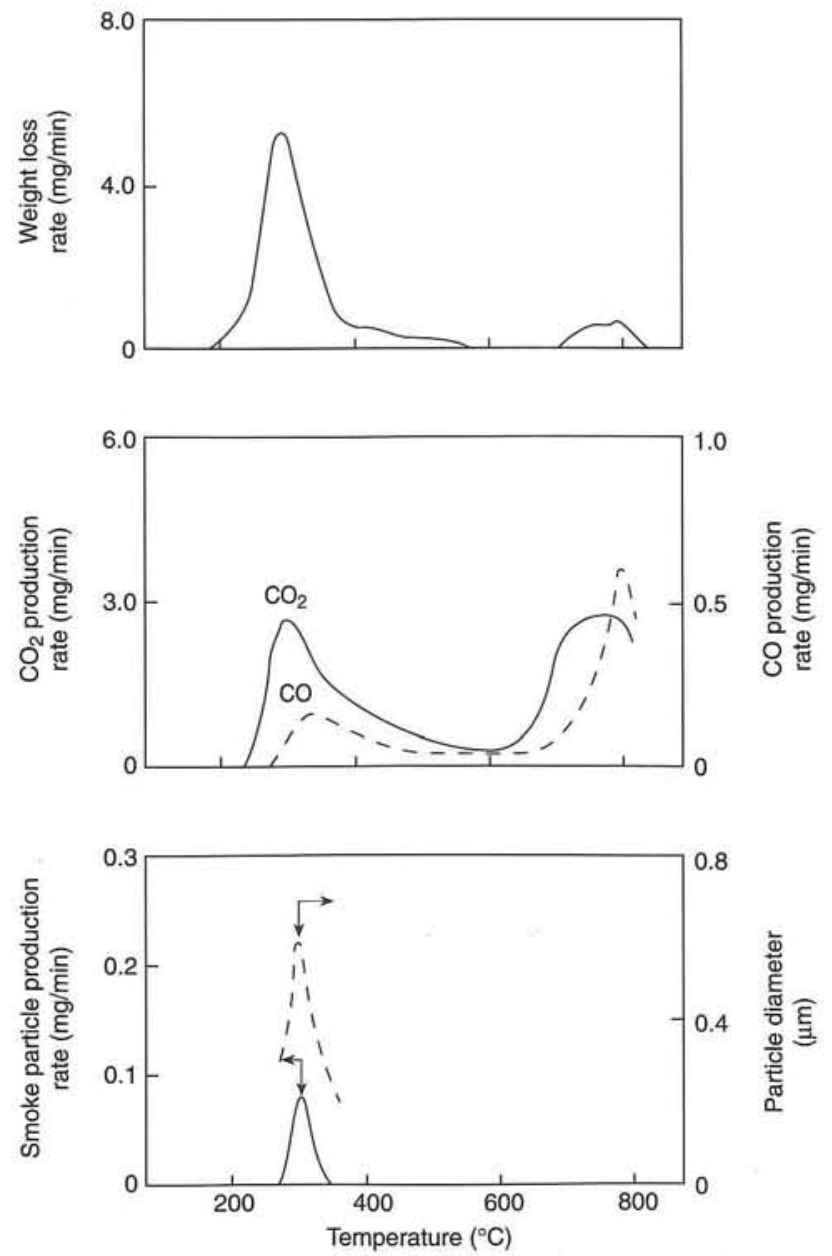
Figure $6 a$.

Weight loss rate, and production rates of carbon oxides and smoke particles from $1.00 \mathrm{mg}$ of lignin in air at the heating rate of $10^{\circ} \mathrm{C} / \mathrm{min}$.
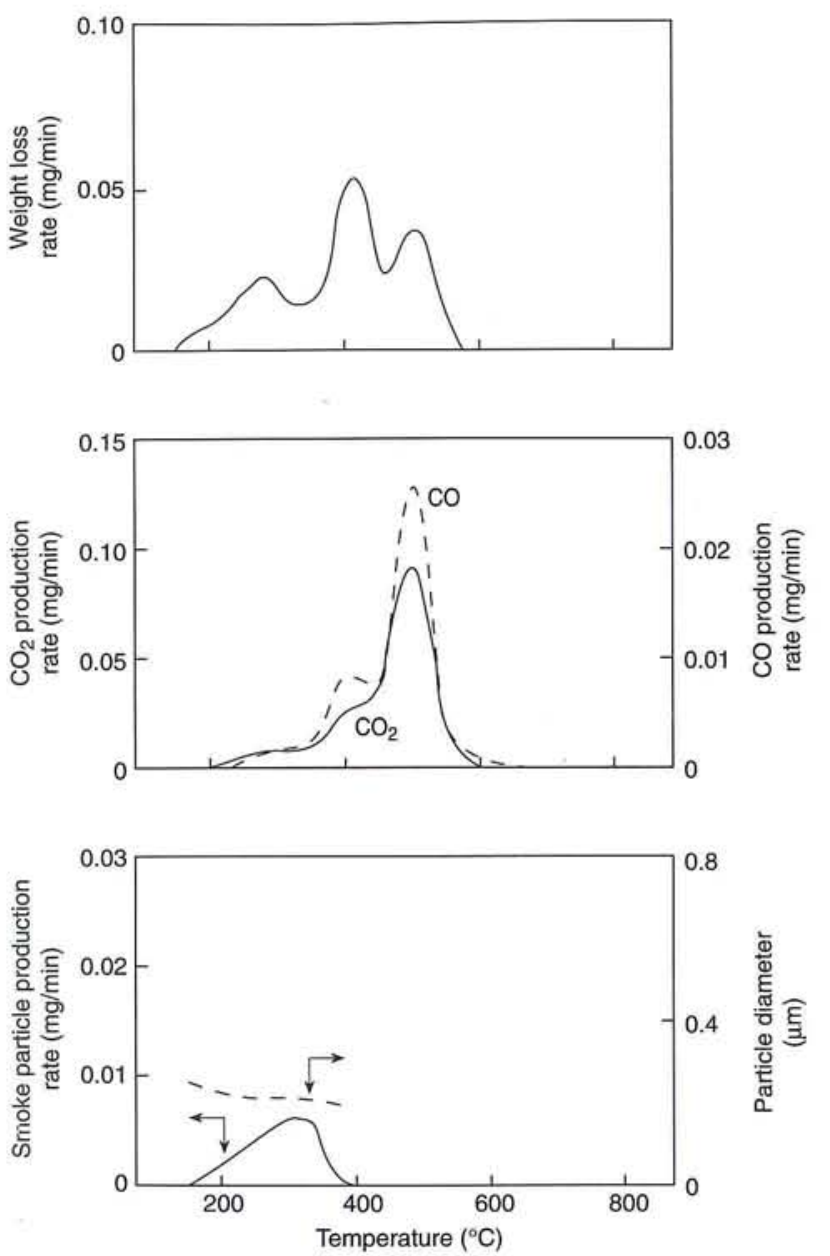

peak in weight loss rate. Particle production was found at temperatures corresponding to only the first maximum in weight loss rate at about $300^{\circ} \mathrm{C}$. When heated in helium, only very small amounts of carbon oxides were produced. However, the production of smoke particulate mass was much higher than in air.

When lignin was heated at a rate of $240^{\circ} \mathrm{C} / \mathrm{min}$, the production rate was found to increase more than ten times, particularly for carbon oxides, as shown in Figures $6 c$, d. It should be noted that production of carbon oxides continued over a wide range of temperatures. Further, the geometric mean diameter of the smoke particles was approximately the same throughout a wide temperature range at any heating rate and in any atmosphere.

\section{DISCUSSION}

The present study shows that the production of carbon oxides is strongly dependent upon the presence of oxygen. When cell wall materials were heated in air, carbon
Figure 6b.

Weight loss rate, and production rates of carbon oxides and smoke particles from $1.02 \mathrm{mg}$ of lignin in helium at the heating rate of $10^{\circ} \mathrm{C} / \mathrm{min}$.
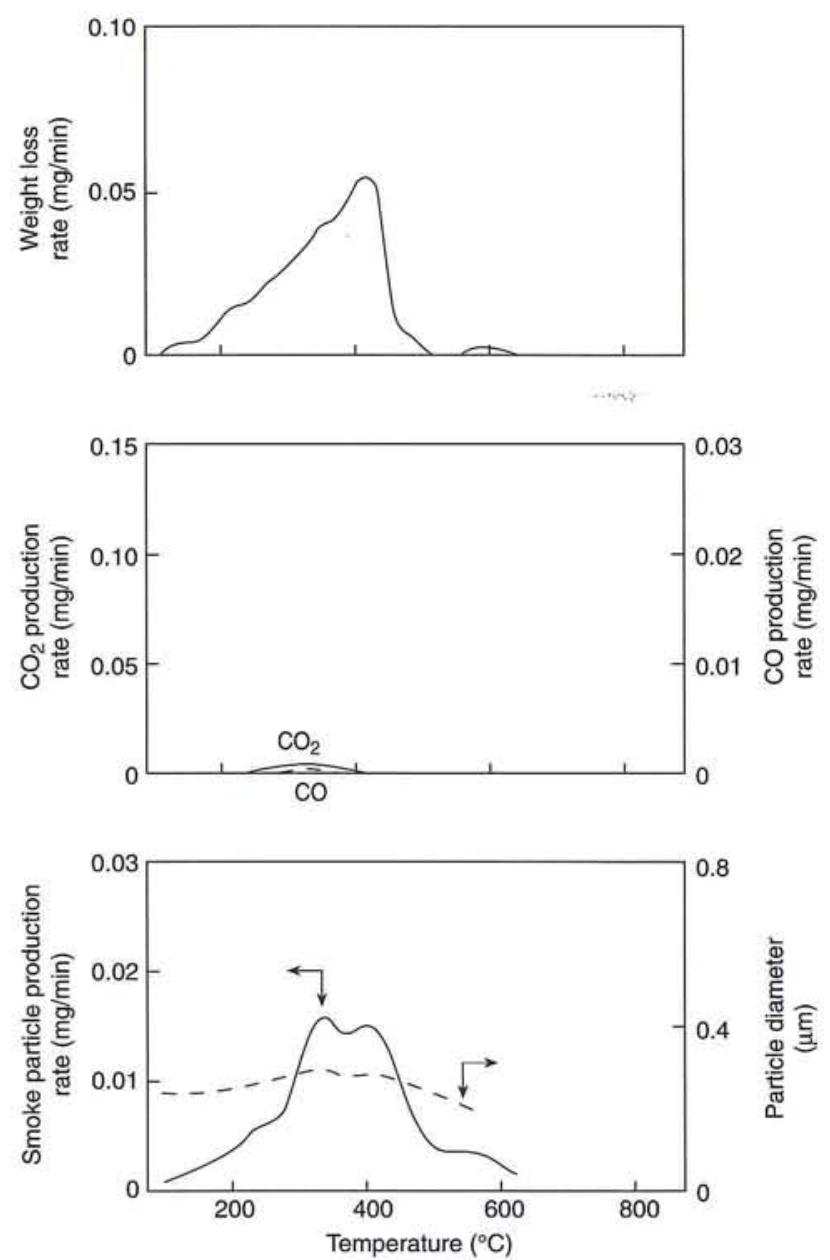

oxides were produced in quantity while in helium, smaller amounts of carbon oxides were produced. Furthermore, a tendency was found at higher temperatures for the production of carbon dioxide to be dominant in air while, in helium, carbon monoxide production was dominant.

Figure 7 summarizes the relation between the total weight of smoke particles produced and the weight of sample power for $\alpha$-cellulose under four different smoke production conditions. It is apparent that the weight of smoke particles produced was larger at faster heating rates and/or in an atmosphere of helium.

It is said that the major decomposition product from pyrolysis of cellulose is levoglucosan (9). Levoglucosan further decomposes with heat to form flammable gases. Accordingly, it can be assumed that when cellulose is heated in air, combustion occurs and the heat of combustion may contribute to the decomposition of considerable amounts of the particulate matter.

When the heating rate is fast, decomposition products generate so rapidly that the formation of particulate matter may predominate over the further decomposition to gaseous materials. 
Figure 6c.

Weight loss rate, and production rates of carbon oxides and smoke particles from $0.56 \mathrm{mg}$ of lignin in air at the heating rate of $240{ }^{\circ} \mathrm{C} / \mathrm{min}$.
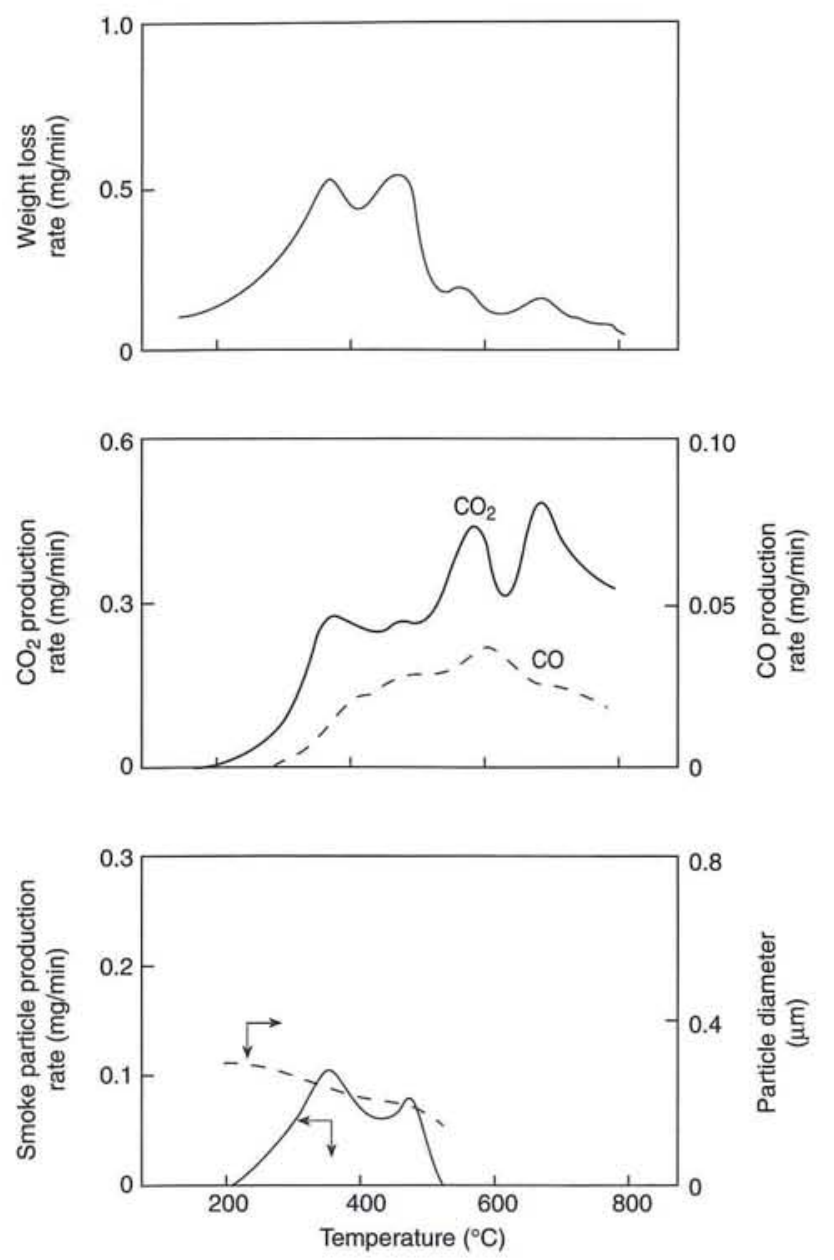

In addition, it should be noticed that the linear regression lines seen in the analysis of results in air and in helium at $10^{\circ} \mathrm{C} / \mathrm{min}$ do not intercept at the origin. This may indicate that there is a threshold concentration of vapours required to form particles. Moreover, when particles were first detected by the laser counter, derivatives of the weight loss rate were about $0.03 \mathrm{mg} / \mathrm{min}^{2}$, regardless of the atmosphere, heating rate or sample weight.

Figure 8 summarizes the results of particle production for hemicellulose. As stated previously, no particles were found at the heating rate of $10^{\circ} \mathrm{C} / \mathrm{min}$. It is known that hemicellulose is primarily composed of xylan, and the major initial degradation products of xylan by pyrolysis have been reported to be 2-furaldehyde and 3-hydroxy-2penteno-1,5-lactone; the former is volatile and the latter is labile (10). Accordingly, particulate mass may be produced less from the thermal degradation of hemicellulose. When the heating rate was fast, particles appeared due to the rapid production of above mentioned degraded materials although the amount was small. Evaporation of these
Figure 6d.

Weight loss rate, and production rates of carbon oxides and smoke particles from $0.65 \mathrm{mg}$ of lignin in helium at the heating rate of $240^{\circ} \mathrm{C} / \mathrm{min}$.
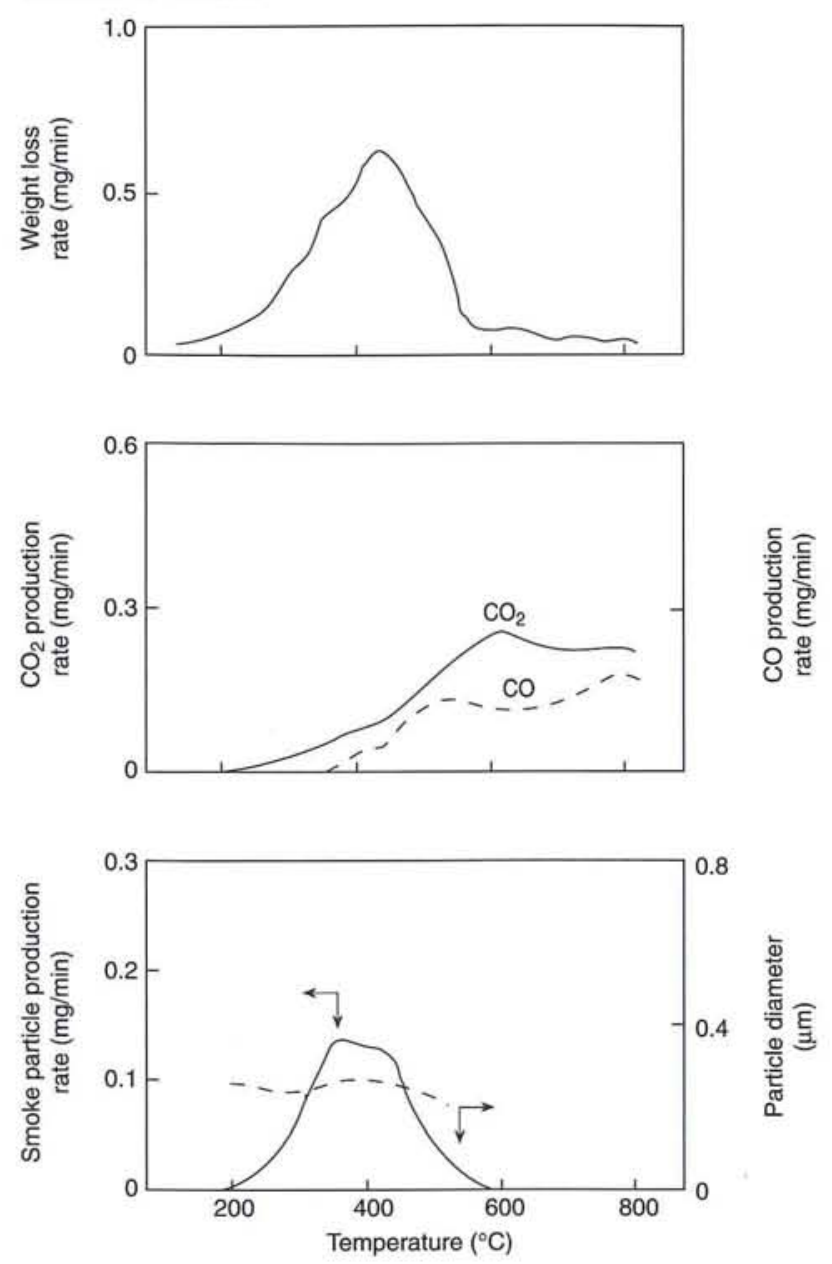

compounds may be suppressed by high concentration and may occur to form particles by condensation and/or coagulation.

The results of particle production for pectin are summarized in Figure 9. Much smaller amounts of smoke particles were found at $240^{\circ} \mathrm{C} / \mathrm{min}$ and no particles at $10^{\circ} \mathrm{C} / \mathrm{min}$.

Results for lignin are summarized in Figure 10. Since the main structures of lignin are a syringyl or guaiacyl group, phenols or hydroxy aromatic compounds are probable products of thermal decomposition (11). Thus, the particles produced in these cases may be expected to contain many phenols.

Figure 11 shows a comparison of the contributions to the particle formation of $\alpha$-cellulose, hemicellulose, pectin and lignin in helium at $240^{\circ} \mathrm{C} / \mathrm{min}$, conditions which approximate to the combustion zone of a cigarette. It is apparent from this Figure that $\alpha$-cellulose and lignin produce much more particulate mass, while hemicellulose and pectin produce much less. The percentage by weight of particles 
Figure 7.

Influence of different heating conditions on the relation between weight of smoke particles produced and sample weight for $\alpha$-cellulose; $\bigcirc$ air, $10^{\circ} \mathrm{C} / \mathrm{min}, \square$ helium, $10^{\circ} \mathrm{C} / \mathrm{min}$, air, $240^{\circ} \mathrm{C} / \mathrm{min}$., a helium, $240^{\circ} \mathrm{C} / \mathrm{min}$.

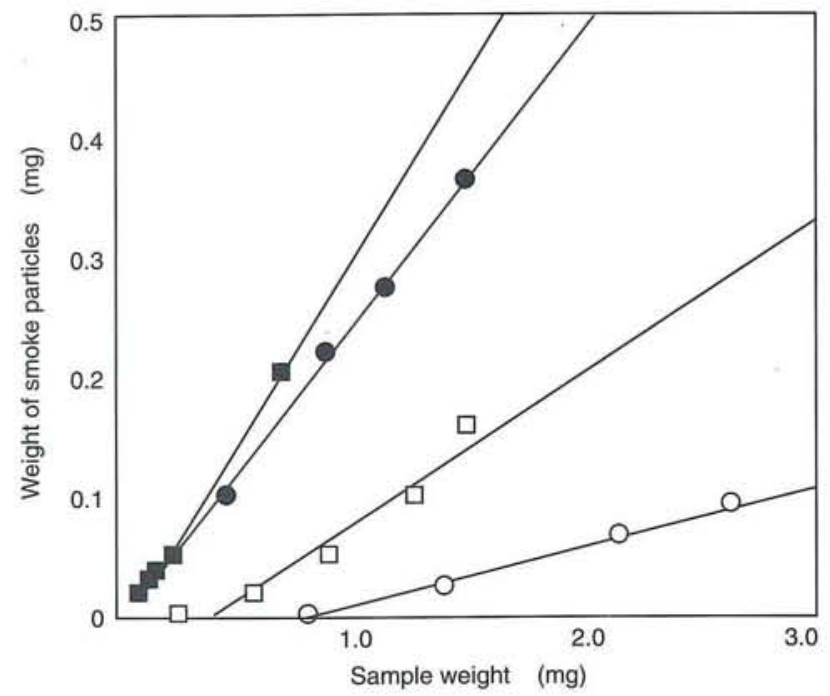

Figure 8.

Influence of different heating conditions on the relation between weight of smoke particles produced and sample weight for hemicellulose; air, $240^{\circ} \mathrm{C} / \mathrm{min}$, $\square$ helium, $240^{\circ} \mathrm{C} / \mathrm{min}$.

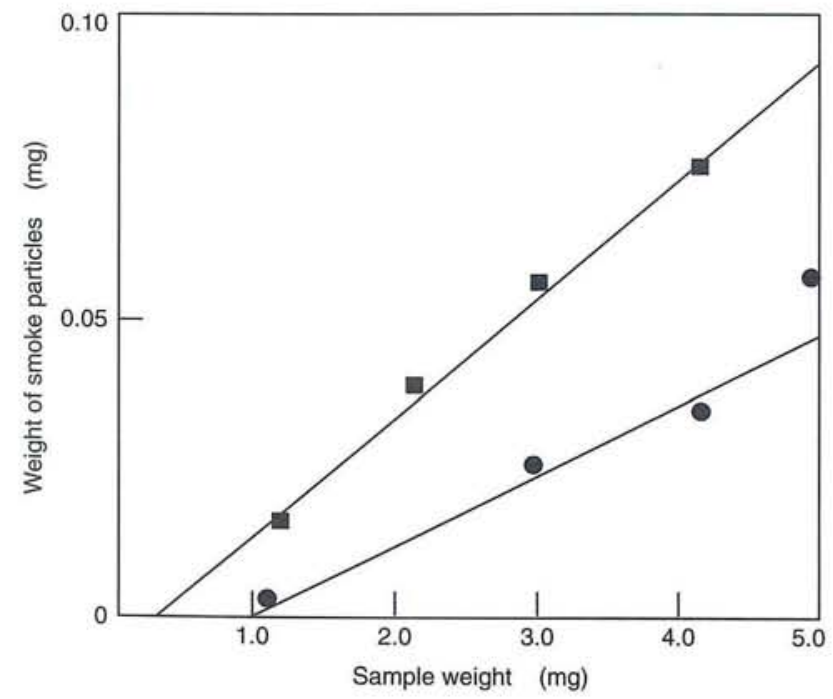

Figure 9.

Influence of different heating conditions on the relation between weight of smoke particles produced and sample weight forpectin; air, $240^{\circ} \mathrm{C} / \mathrm{min}$, $\square$ helium, $240^{\circ} \mathrm{C} / \mathrm{min}$.

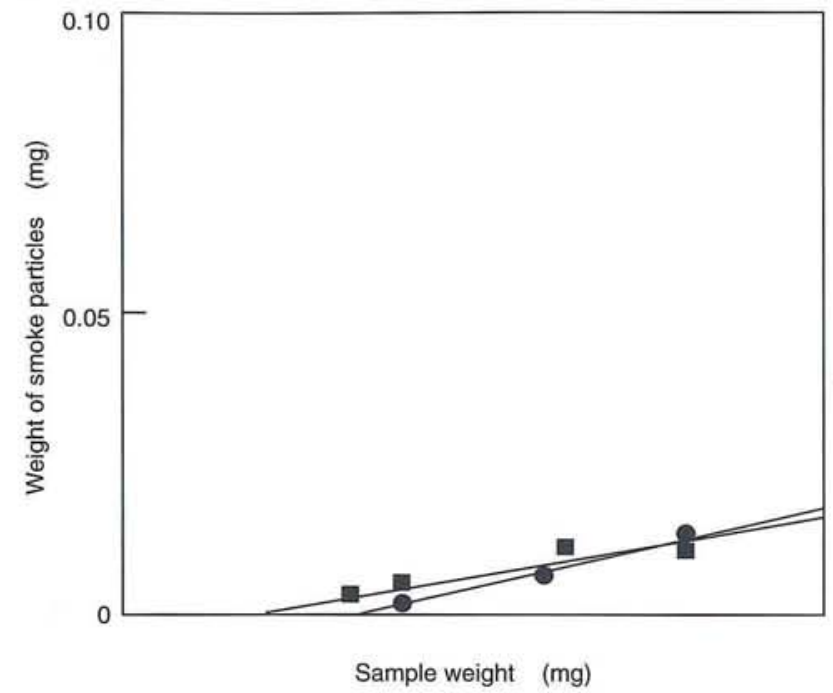

Figure 10.

Influence of different heating conditions on the relation between weight of smoke particles produced and sample weight forlignin; $\bigcirc$ air, $10^{\circ} \mathrm{C} / \mathrm{min}, \square$ helium, $10^{\circ} \mathrm{C} / \mathrm{min}, ~ a i r$, $240^{\circ} \mathrm{C} / \mathrm{min}$, 回 helium, $240^{\circ} \mathrm{C} / \mathrm{min}$.

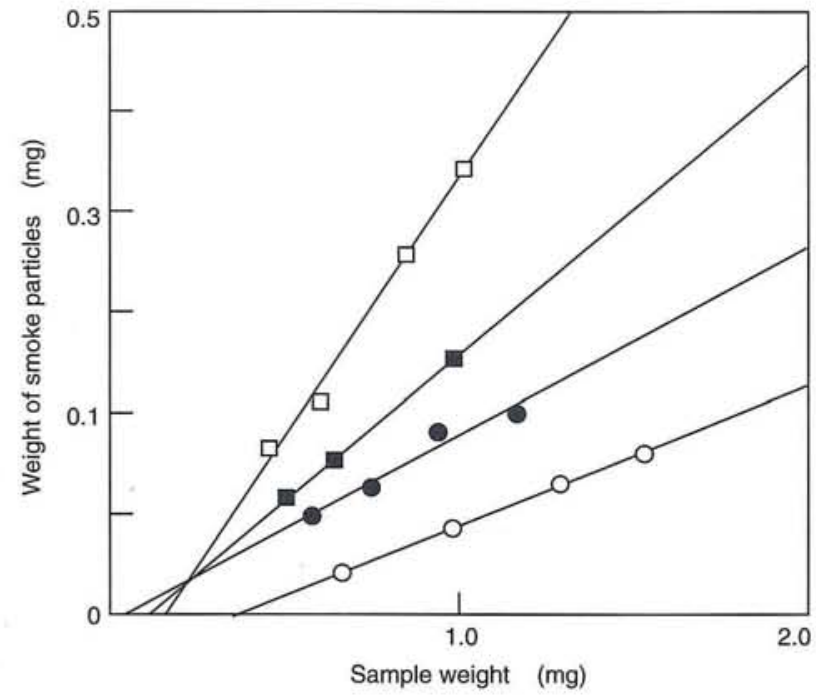


Figure 11.

Comparison of the capability of particle formation among four cell-wall materials in helium at the heating rate of $240^{\circ} \mathrm{C} / \mathrm{min}$.

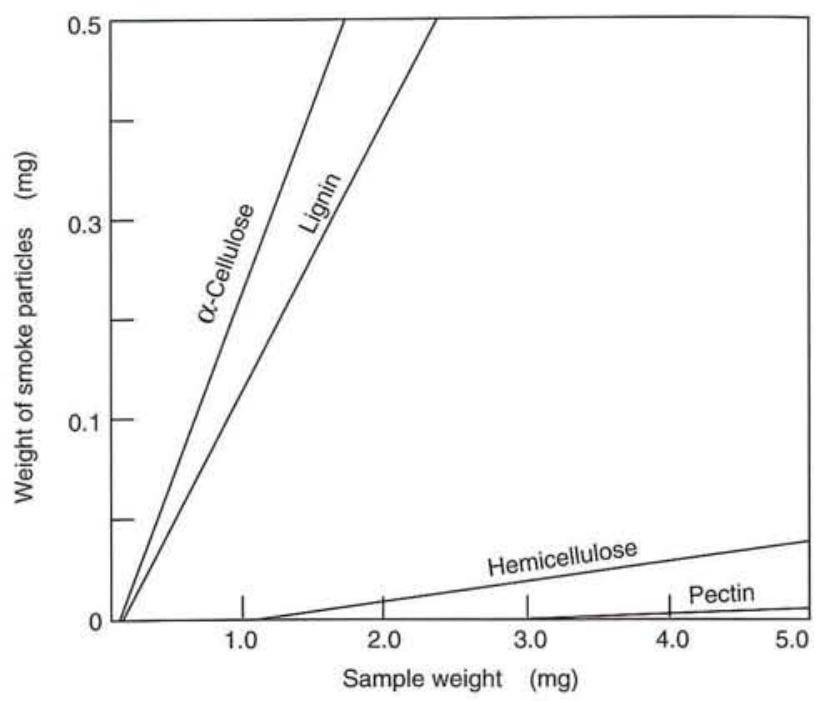

produced to the sample weight was $32 \%$ for $\alpha$-cellulose, $24 \%$ for lignin, $3 \%$ for hemicellulose and $0.4 \%$ for pectin. The percentage by weight of these materials in dry tobacco leaves are $10-20 \%$ for $\alpha$-cellulose, $5-8 \%$ for hemicellulose, $3-8 \%$ for pectin and $2-3 \%$ for lignin. Although the smoke formation mechanism of the isolated materials and real cigarettes is not the same, it may be concluded that $\alpha$-cellulose contributes most to the formation of smoke particles from cigarettes. On the other hand, pectin contributes least.

\section{REFERENCES}

1. Stober, W.: Generation, size distribution and composition of tobacco smoke aerosols; in Recent advances in tobacco science, Vol 8: The 36th Tob. Chem. Res. Conf., Raleight, N.C., 1982, pp. 3-41.

2. Shafizadeh, F, K. V. Sarkanen and D. A. Tillmann: Thermal uses and properties of carbohydrates and lignin; Academic Press, New York, N.Y., 1976, p. 276.
3. Burton, H. R. and G. Childs, Jr.: Thermal decomposition of tobacco; Beitr. Tabakforsch. 9 (1977) 45-52.

4. Baker, R. R.: Product formation mechanisms inside a burning cigarette; Prog. Energy Combust. Sci. 7 (1981) 135-153.

5. Baker, R. R.: A review of pyrolysis studies to unravel reaction steps in burning tobacco; J. Anal. Appl. Pyrol. 11 (1987) 555-573.

6. Ishizu, Y., K. Ohta and H. Tomita: Physical properties of tobacco smoke particles produced under different conditions; Beitr. Tabakforsch. Int. 12 (1984) 137-146.

7. Whistler, R. L. (ed.): Method in carbohydrate chemistry Vol III; Academic Press, New York, N.Y., 1963.

8. Muramatsu, M.: Studies on the transport phenomena in a static burning cigarette; Sci. Paper. Cent. Res. Inst. Japan tobacco \& Salt Public Corp. 123 (1981) 39-46.

9. Chatterjee, P. K. and C. M. Conrad: Kinetics of the pyrolysis of cotton cellulose; Text. Res. J. 36 (1966) 487-494.

10. Ohnishi, A. and K. Kato: Thermal decomposition of tobacco cell wall polysaccharides; Beitr. Tabakforsch. 9 (1977) 147-152.

11. Kato K. F. Sakai and T. Nakahata: Thermal decomposition of tobacco lignin in Japanese; Sci. Paper. Cent. Res. Inst. Japan Monopoly Corp. 107 (1965) $171-175$.

\section{Authors' address}

Tobacco Science Research Laboratory

Japan Tobacco Inc.

6-2 Umegaoka, Midori-ku,

Yokokama,

Kanagawa 227,

Japan. 